\title{
Evaluation of the presence and zoonotic transmission of Chlamydia suis in a pig slaughterhouse
}

\author{
Kristien De Puysseleyr ${ }^{1 *}$, Leentje De Puysseleyr ${ }^{1+}$, Hendrik Dhondt ${ }^{2}$, Tom Geens $^{2}$, Lutgart Braeckman ${ }^{3}$, \\ Servaas A Morré 4,5 , Eric Cox ${ }^{6}$ and Daisy Vanrompay ${ }^{1}$
}

\begin{abstract}
Background: A significant number of studies on pig farms and wild boars worldwide, demonstrate the endemic presence of Chlamydia suis in pigs. However, the zoonotic potential of this pathogen, phylogenetically closely related to Chlamydia trachomatis, is still uninvestigated. Therefore, this study aims to examine the zoonotic transmission in a Belgian pig abattoir.
\end{abstract}

Methods: Presence of Chlamydia suis in pigs, contact surfaces, air and employees was assessed using a Chlamydia suis specific real-time PCR and culture. Furthermore, Chlamydia suis isolates were tested for the presence of the tet(C) gene.

Results: Chlamydia suis bacteria could be demonstrated in samples from pigs, the air and contact surfaces. Moreover, eye swabs of two employees were positive for Chlamydia suis by both PCR and culture. The tet(C) gene was absent in both human Chlamydia suis isolates and no clinical signs were reported.

Conclusions: These findings suggest the need for further epidemiological and clinical research to elucidate the significance of human ocular Chlamydia suis infections.

Keywords: Chlamydia suis, Swine, Zoonosis, Tetracycline, Public health

\section{Background}

The negative influence of Chlamydiaceae infections on the economic yield of the pig industry is underestimated [1]. Four chlamydial species are regularly observed in the pig population: Chlamydia (C.) pecorum, C. abortus, C. psittaci and C. suis [1]. Chlamydia suis is the most prevalent and its primary pathogenicity is proven by several experimental infections in gnotobiotic pigs [2-8]. In field, this pathogen is mainly associated with respiratory disease, diarrhea, conjunctivitis, reproductive failure and subclinical infections $[1,8]$. Chlamydiae are generally highly sensitive to the relatively inexpensive tetracycline antibiotics. However, the first tetracyline resistant $\left(\mathrm{Tc}^{\mathrm{R}}\right)$ C. suis strains appeared in the U.S. in 1998 [9]. Ever

\footnotetext{
*Correspondence: Kristien.DePuysseleyr@ugent.be

${ }^{\dagger}$ Equal contributors

'Department of Molecular Biotechnology, Faculty of Bioscience Engineering, University of Ghent, Coupure Links 653, B-9000 Gent, Belgium

Full list of author information is available at the end of the article
}

since, infections with C. suis strains have been reported on Italian [10,11], Estonian [12], Belgian, Cypriot, German, Israeli [13], Swiss [14] and Dutch [15] pig farms. The majority of these infections were due to $\mathrm{Tc}^{\mathrm{R}}$ C. suis strains. Moreover all of these farms suffered from severe reproductive failure leading to marked economic loss.

Exposure to $\mathrm{Tc}^{\mathrm{R}}$ C. suis strains poses an additional risk for pig handlers. In fact, Suchland et al. [16] demonstrated horizontal transfer of the tetracycline resistance gene tet $(\mathrm{C})$ among chlamydial species.

The use of tetracycline antibiotics as treatment for chlamydial infections in pigs, leads to selection for resistant strains [14]. Consequently, the emergence of $\mathrm{Tc}^{\mathrm{R}}$ strains requires the use of other, more expensive antibiotics and, may become economically devastating to pig production. Besides the economical consequences, $\mathrm{Tc}^{\mathrm{R}}$ C. suis strains are also a potential threat to public health. Contact between $\mathrm{Tc}^{\mathrm{R}}$ C. suis and tetracycline sensitive C. trachomatis bacteria might lead to creation 
of a $\mathrm{Tc}^{\mathrm{R}}$ C. trachomatis strain in persons infected with both strains. Nevertheless, the co-infection of a person with $C$. suis and $C$. trachomatis is only possible if $C$. suis is a zoonotic bacteria. Albeit the zoonotic potential of $C$. suis is still unexamined, the zoonotic transfer of C. suis is a plausible hypothesis since C. suis is phylogenetically highly related to $C$. trachomatis, a natural pathogen of humans [17]. Therefore, the present study examines the prevalence of $C$. suis in butcher hogs $( \pm 100 \mathrm{~kg})$ being slaughtered in a Belgian abattoir, and simultaneously investigates zoonotic transmission. For this purpose, slaughterhouse employees, air and possible direct contact surfaces were sampled. Pigs, air and contact surfaces were diagnosed for $\mathrm{Tc}^{\mathrm{R}} C$. suis, while humans were examined for $\mathrm{Tc}^{\mathrm{R}} C$. suis and C. trachomatis. As far as known, the present study is the first evaluation of the zoonotic potential of $C$. suis in a pig slaughterhouse.

\section{Methods}

\section{Sampling of pigs and humans}

Rayon-tipped aluminium-shafted swabs (Copan; Fiers, Kuurne, Belgium) were used to sample pigs and humans. For monitoring C. suis in pigs, rectal swabs ( $\mathrm{n}=100 ; 10$ pigs of 10 Belgian farrowing to slaughter farms) were taken upon arrival in the slaughterhouse. No information on clinical signs or medication during the fattening period was available. Sampling was performed on one day. A swab for PCR was placed in DNA/RNA stabilization buffer (Roche) and a swab for culture was immersed in chlamydia transport medium (2-SP). At the same day, employees voluntarily provided (informed consent) an ocular and pharyngeal swab, and they were asked to bring a fresh stool swab and a first void morning urine sample the next day. All samples were kept at $4^{\circ} \mathrm{C}$ and they were stored at $-80^{\circ} \mathrm{C}$ upon arrival in the laboratory. Volunteers filled out a medical questionnaire, in the presence of a medical doctor, to assess information on professional (work environment of the employee) and nonprofessional activities, general health status, smoking habits, use of medication, allergies and clinical signs.

This study was approved by the medical ethical committee of Ghent University (approval EC UZG 2011/459). Participants provided their written informed consent and the consent procedure was approved by the medical ethical committee.

\section{Sampling of air and contact surfaces}

Bioaerosol monitoring for C. suis was performed using the MAS-100 Eco sampler (Merck, Darmstadt, Germany) as previously described [18] at different locations in the abattoir: the pig reception area (lairage and stunning), slaughtering and bleeding area, pre-washing bath location, dehairing area, cutting/deboning area, carcass splitting area, organ evisceration area, individual weighing area, chilling/hanging room, pig intestine washing room, employee dining room, and the administrative office. In addition, also contact surfaces were sampled (water taps, door handles, tables, knives, start and stop button of machines) at all these locations by use of rayontipped aluminium-shafted swabs (Copan; Fiers, Kuurne, Belgium). Swabs were examined by PCR and culture. In addition, we also sampled water taps and door handles at the sanitary facilities at the individual weighing area, the pig intestine washing room and the cloakrooms.

\section{DNA extraction}

DNA extraction on urine samples was performed by the High Pure PCR Template Preparation (HPPTP) Kit (Roche Molecular Biochemicals, Mannheim, Germany), according to the manufacturers' protocol (version 16.0). DNA extraction of swabs and chlamydia cell culture harvest was performed as described by Wilson et al. [19].

\section{Chlamydia suis PCR}

Pig swabs were examined by real-time PCRI, a 23S rRNAbased real-time PCR detecting C. suis in pigs [20]. However, this PCR analysis cannot be used for examining transfer of C. suis to humans, as it also detects C. trachomatis. Therefore, all pig and human samples were also examined by real-time PCRII, a recently developed $C$. suis-specific $23 \mathrm{~S}$ rRNA-based real-time PCR [15]. This allowed the comparison between real-time PCRI and II, for examining C. suis. Similarly, all air and contact surface samples were analysed with PCRI and II. Samples with a Ct-value below 35 cycles, were retested twice. Only repeatedly positive samples were judged as positive. Genomic DNA of the C. suis reference strain S45 was used as positive control DNA ( $10^{5}$ particles per reaction), and DNAse -RNAse free water as negative control.

\section{Chlamydia trachomatis PCR}

All ocular and pharyngeal swabs and urine samples of the employees were tested for presence of C. trachomatis DNA using the CE-IVD certified PRESTO Kit (Goffin Molecular Diagnostics, Houten, The Netherlands) according to manufacturer's instructions [21].

\section{Culture}

All samples were examined for viable chlamydial bacteria in cycloheximide-treated Vero cells using standard techniques [22]. Positive cells were enumerated in five randomly selected microscopic fields (600x, Nikon Eclipse TE2000-E, Japan) and results were scored from 0 to 6 . Score 0 indicated that no Chlamydiae were present; Score 1 was given when a mean of 1 to 5 non-replicating elementary bodies (EB's) plus maximum one inclusion 
(elementary and replicating reticulate bodies) with multiplying EB's was observed; scores 2 to 5 were given when observing a mean of 2 to 5,6 to 10,11 to 15,16 to $>90 \%$ inclusion positive cells [23].

\section{Molecular characterization of Chlamydia isolates}

Chlamydial isolates were molecularly characterized by real-time PCRII [15] and DNA sequence analysis of the $16 \mathrm{~S}$ (298 bp) and 23S (627 bp) signature sequences of Chamydia [17]. Sequence analyses were performed by the VIB Genetic Service Facility (University of Antwerp, Antwerp, Belgium).

\section{Tet(C) PCR}

Chlamydia suis isolates of pigs and humans were examined for presence of the tetracycline resistance gene by the tet(C) PCR, as described by Dugan et al. [24].

\section{Results}

\section{Chlamydia suis in pigs}

Rectal swabs of 100 pigs were examined by real-time PCRI and II. Real-time PCRI revealed 45 (45\%) positives. The Ct-values varied between 26.6 and 32 . PCRII discovered 7 additional positives, resulting in a final number of 52 positives on 100 (52\%) pigs (with the 95 percentage confidence interval ranging from 24 to $66 \%$ ). This finding is consistent with the reported higher sensitivity of PCRII [15] compared to PCRI [20]. The Ct-value of realtime PCRII varied between 16.8 and 30.1. PCRII positive pigs were found on all farms. The percentage of PCRII positive pigs per farm ranged from 10 to $100 \%$. Fifteen of 52 (28.8\%) PCR positive pigs excreted C. suis, as demonstrated by PCRII and DNA sequencing of $16 \mathrm{~S}$ and 23S signature sequences of obtained Chlamydia isolates. Those 15 culture positives originated from 8 of 10 examined farms. Three of 15 (20\%) C. suis isolates contained the tet $(\mathrm{C})$ gene (Figure 1). Chlamydia suis tet $(\mathrm{C})$ positives were found on 3 of 10 farms.

\section{Chlamydia suis and Chlamydia trachomatis in humans}

Only 12 of 84 (14.3\%) employees participated. The age of the participants varied between 25 and 60 years with an average of 43 years. The set of 48 human samples

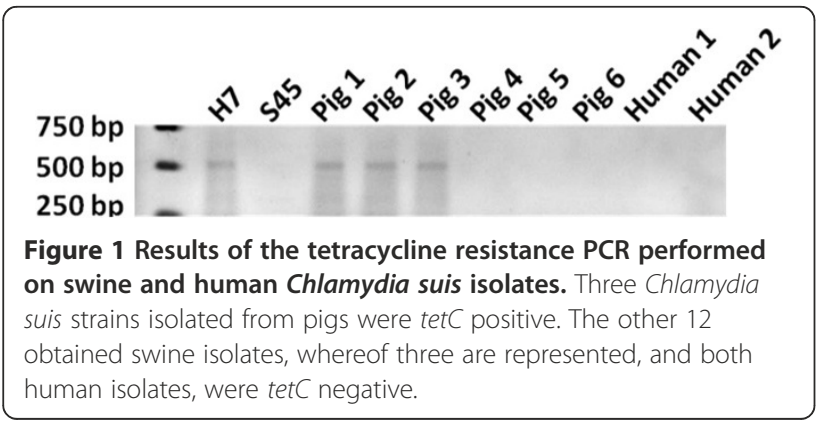

comprised: 12 conjunctival, 12 pharyngeal, 12 stool and 12 urine samples, which were all examined for C. suis and C. trachomatis. Samples were negative for C. trachomatis. Pharyngeal, stool and urine samples were negative for $C$. suis by both real-time PCRI and II. However, 2 of $12(16.6 \%)$ conjunctival swabs were positive in real-time PCRII, showing Ct-values of 26 and 28, respectively. Those two swabs were negative by real-time PCRI. Positive real-time PCRII results were confirmed by culture (both score 1), as we isolated C. suis from both conjunctival swabs (Figure 2). None of the human C. suis isolates contained the tet $(\mathrm{C})$ gene (Figure 1$)$. Both $C$. suis positive employees worked daily in the abattoir. One of them worked in the pig intestine washing room during the last three years while the other person did the bleeding of the pigs during the last eight years. They had no clinical signs or disease complaints while being examined by the occupational physician, nor did they mention having symptoms related to eye infections, ever since working in the slaughterhouse.

\section{Chlamydia suis on contact surfaces}

Contact surfaces were all negative by real-time PCRI. Realtime PCRII could discover C. suis DNA, albeit small amounts (Ct-values ranging from 32.5 to 34.1 ) were detected on contact surfaces of nine of the 14 sampled work locations in the slaughterhouse. For six of these locations, positive real-time PCRII results were confirmed by culture (culture score 1) (Table 1).

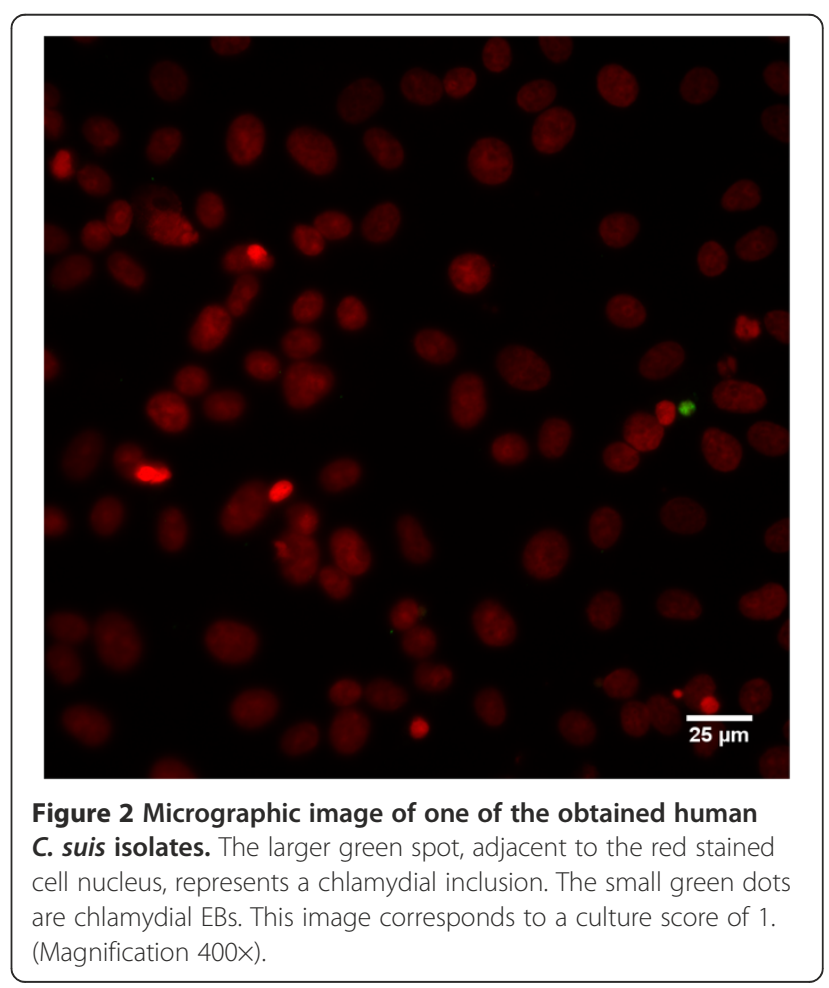


Table 1 Results of the molecular analyses on contact surface samples at different locations in the abattoir

\begin{tabular}{lll}
\hline Location & PCRII & $\begin{array}{l}\text { Viable } \\
\text { C. suis }\end{array}$ \\
\hline Pig reception area & - & - \\
Slaughtering and bleeding area & + & + \\
Pre-washing bath location & - & - \\
Dehairing area & + & + \\
Cutting/deboning area & - & - \\
Carcass splitting area & + & - \\
Organ evisceration area & - & - \\
Individual weighing area & + & + \\
Chilling/hanging room & - & - \\
Pig intestine washing room & + & - \\
Employee dining room & + & + \\
Sanitary facilities at the individual wheighing area & + & - \\
Sanitary facilities at the pig intestine washing room & + & + \\
Sanitary facilities at the cloakrooms & + & + \\
Total (positives/examined) & $\mathbf{9 / 1 4}$ & $\mathbf{6 / 1 4}$ \\
\hline
\end{tabular}

Swabs in DNA/RNA stabilization buffer were used to detect the presence of $C$. suis DNA by use of PCRI and II. The results of the PCRII analysis are mentioned in column 'PCRII'. Swabs in 2-SP medium were inoculated on Vero-cells for evaluation of the presence of viable Chlamydiae. Culture positive chlamydial isolates were analysed using PCRII for subsequent molecular detection of $C$. suis. Results are shown in column 'viable $C$. suis'. All culture positive samples showed isolation score 1 .

\section{Chlamydia suis bioaerosol monitoring}

Air samples were all negative by real-time PCRI. Realtime PCRII could discover small amounts of $C$. suis DNA (Ct-values ranging from 32.5-34.12) in the air of seven of ten sampled locations. Positive real-time PCRII results were confirmed by culture for five of these locations (Table 2).

\section{Discussion}

The present study examines the occurrence of $\mathrm{Tc}^{\mathrm{R}}$ C. suis strains in butcher hogs being slaughtered in a Belgian abattoir and, at the same time, is focusing on zoonotic transmission of C. suis. Chlamydia suis infections are emerging worldwide in the pig industry [1]. Increased awareness of veterinarians and improved diagnostics might explain, albeit partially, the increasing number of reports on C. suis outbreaks in pigs $[20,25]$. However, we are unaware if contact with $C$. suis infected pigs presents a public health risk, in particular for pig farmers and abattoir employees. After all, Chlamydia suis is phylogenetically highly related to the human pathogen Chlamydia trachomatis [17]. Moreover, both pathogens cause infections of the eye and urogenital tract in their natural hosts (reviewed by Schautteet and Vanrompay [1]). Recently, Dean et al. examined 101 conjunctival samples of trachoma (preventable blindness) patients who resided in a trachoma-endemic region
Table 2 Results of the molecular analyses on air samples at different locations in the abattoir

\begin{tabular}{llll}
\hline Location & PCRII & $\begin{array}{l}\text { Viable } \\
\text { C. suis }\end{array}$ & $\begin{array}{l}\text { Isolation } \\
\text { score }\end{array}$ \\
\hline Pig reception area & + & - & 4 \\
Slaughtering/bleeding area & + & - & - \\
Pre-washing bath location & + & + & 2 \\
Dehairing area & + & + & 2 \\
Organ evisceration area & + & + & 1 \\
Individual wheighing area & - & - & - \\
Chilling/hanging room & + & + & 2 \\
Pig intestine washing room & + & + & 4 \\
Dining room & - & - & - \\
Administration office & - & - & - \\
Total (positives/examined) & $\mathbf{7 / 1 0}$ & $\mathbf{5 / 1 0}$ & \\
\hline
\end{tabular}

All samples were used for direct detection of C. suis DNA, by use of PCRI and II (results in column 'PCRII'), for inoculation on Vero cells (results in column 'Isolation score') and subsequent identification of C. suis (column 'viable C. suis').

of Nepal [26]. They found two C. suis infections and five mixed C. trachomatis plus C. suis infections, all leading to trachomatous inflammation. Hence, zoonotic transmission is likely.

Besides, the number of reports on $\mathrm{Tc}^{\mathrm{R}}$ C. suis infections in pigs is augmenting $[9,11,13,14,27,28]$. In 2010, Schautteet et al. demonstrated tet $(C)$ positive $C$. suis strains in 10 examined Belgian farms and in 8 on 49 (16.3\%) sick pigs ending up in the autopsy room of DGZ-Animal Health Care Flanders [12]. Hence, the previously reported epidemiology of $C$. suis in Belgian pigs is confirmed by the present study since we found tet $(\mathrm{C})$ positive C. suis strains in 8 of 10 examined Belgian farms. Therefore, a pig slaughterhouse is a confirmed risk environment to study the zoonotic transfer of $C$. suis. Employees provided urine and ocular, pharyngeal and fresh stool swab specimens for both PCR and culture. Two of 12 examined employees tested positive for C. suis by PCR and culture. However, only 12 of $84 \mathrm{em}-$ ployees participated, which was low compared to former similar studies on C. psittaci zoonotic transmission in poultry abattoirs [18]. Analysis of the answers on all questionnaires indicated that there were no clinical complaints, and the yearly routine medical examination revealed no clinical signs of infection, although viable $C$. suis were found in the eyes of two employees. Both individuals worked for several years in the abattoir, in the pig intestine washing room and in the slaughtering and bleeding area, respectively. Thus, exposure to blood and intestinal contents seems to present a risk for transmission to humans, but it is not strictly leading to a symptomatic course of infection. Employees are almost continuously exposed to $C$. suis and therefore could have 
natural immunity against disease. Serological analyses could have clarified this issue, however, employees did not give their consent for blood sampling. Contact surfaces at both locations were equally positive by both PCR and culture. Thus, Chlamydia suis could have ended up in the eyes through direct contact of hands with 'contaminated' contact surfaces. Besides, bioaerosol monitoring demonstrated high amounts (score 4) of viable C. suis in the air of the slaughtering and bleeding area. On the other hand, the air of the intestine washing room was C. suis negative, which could indicate that the air is not the main C. suis transmission route. However, further studies on larger risk populations should be conducted to get more insights into transmission routes and clinical consequences of $C$. suis in humans.

\section{Conclusion}

The present study shows the presence of viable C. suis bacteria in the eyes of two employees and in air samples and contact surfaces along the slaughter line. None of the human C. suis isolates contained the tet $(C)$ gene and both humans were negative for $C$. trachomatis. However, the adaptive ability of $C$. suis to acquire the tet $(\mathrm{C})$ gene, especially when exposed to selective pressure, and the possibility of $C$. suis transfer to humans could have far-reaching consequences for public health. Preventive measures might reduce the risk of $C$. suis transfer to slaughterhouse employees. Besides, further epidemiological and clinical research towards human ocular C. suis infections is of great importance.

\section{Competing interests}

The authors declare that they have no competing interests.

\section{Authors' contributions}

LDP and KDP participated in the design of the study, carried out the sampling, performed the majority of the experimental work (C. suis real time $P C R$, culture in Vero cells, tet(C) PCR) and drafted the manuscript. HD, TG and $L B$ were involved in the conception of the study, the application for approval by the medical ethical committee, and the sampling. SAM performed the experimental analyses for C. trachomatis and revised the manuscript critically. EC and DV participated in the experimental work (tet(C) PCR and Everett PCR analyses) and helped to draft the manuscript. All authors read and approved the final manuscript.

\section{Authors' information}

Eric Cox and Daisy Vanrompay shared senior authorship.

\section{Acknowledgements}

Annelien Dumont, Lien De Vogelaere and Line Devlieger are acknowledged for technical assistance during the experiments.

This study was funded by the Federal Public Service of Health, Safety of the Food Chain and Environment (convention RF-10/6234), Ghent University (IOF/STARTT/002) and MSD Animal Health (Boxmeer, The Netherlands).

\section{Author details}

'Department of Molecular Biotechnology, Faculty of Bioscience Engineering, University of Ghent, Coupure Links 653, B-9000 Gent, Belgium. 'Provikmo, Occupational Health Services, Bruges, Belgium. ${ }^{3}$ Department of Public Health, Faculty of Medicine and Health Sciences, Ghent University, Ghent, Belgium. ${ }^{4}$ Department of Medical Microbiology \& Infection Control, Laboratory of Immunogenetics, VU University Medical Center, Amsterdam, The
Netherlands. ${ }^{5}$ Department of Genetics and Cell Biology, Institute for Public Health Genomics (IPHG), Research School GROW (School for Oncology \& Developmental Biology), Faculty of Health, Medicine \& Life Sciences, University of Maastricht, Maastricht, The Netherlands. ${ }^{6}$ Department of Virology, Parasitology and Immunology, Faculty of Veterinary Medicine, University of Ghent, Ghent, Belgium.

Received: 28 May 2014 Accepted: 14 October 2014

Published online: 30 October 2014

\section{References}

1. Schautteet K, Vanrompay D: Chlamydiaceae infections in pig. Vet Res 2011, 42(1):29.

2. Rogers DG, Andersen AA, Hunsaker BD: Lung and nasal lesions caused by a swine chlamydial isolate in gnotobiotic pigs. J Vet Diagn Invest 1996, 8(1):45-55.

3. Rogers DG, Andersen AA: Intestinal lesions caused by two swine chlamydial isolates in gnotobiotic pigs. J Vet Diagn Invest 1996, 8(4):433-440.

4. Rogers DG, Andersen AA: Conjunctivitis caused by a swine Chlamydia trachomatis-like organism in gnotobiotic pigs. J Vet Diagn Invest 1999, 11(4):341-344

5. Reinhold P, Kirschvink N, Theegarten D, Berndt A: An experimentally induced Chlamydia suis infection in pigs results in severe lung function disorders and pulmonary inflammation. Vet Res 2008, 39(3):35.

6. Reinhold P, Hartmann H, Constable PD: Characterisation of acid-base abnormalities in pigs experimentally infected with Chlamydia suis. Vet $J$ 2010, 184(2):212-218.

7. Guscetti F, Schiller I, Sydler T, Heinen E, Pospischil A: Experimental enteric infection of gnotobiotic piglets with Chlamydia suis strain S45. Vet Microbiol 2009, 135(1-2):157-168.

8. Pospischil A, Borel N, Chowdhury EH, Guscetti F: Aberrant chlamydial developmental forms in the gastrointestinal tract of pigs spontaneously and experimentally infected with Chlamydia suis. Vet Microbiol 2009, 135(1-2):147-156.

9. Andersen AA, Rogers DG: Resistance to tetracycline and sulfadiazine in swine C. trachomatis isolates. In Ninth International Symposium on Human Chlamydial Infection: 1998; San Francisco, Calif. 1998:313-316.

10. Di Francesco A, Donati M, Morandi F, Renzi M, Masia MA, Ostanello F, Salvatore D, Cevenini R, Baldelli R: Seroepidemiologic survey for Chlamydia suis in wild boar (Sus scrofa) populations in Italy. J of Wildlife Dis 2011, 47(3):709-712

11. Di Francesco A, Donati M, Rossi M, Pignanelli S, Shurdhi A, Baldelli R, Cevenini R: Tetracycline-resistant Chlamydia suis isolates in Italy. Vet Rec 2008, 163(8):253-253.

12. Schautteet K, Beeckman DS, Delava P, Vanrompay D: Possible pathogenic interplay between Chlamydia suis, Chlamydophila abortus and PCV-2 on a pig production farm. Vet Rec 2010, 166(11):329-333.

13. Schautteet K, De Clercq E, Miry C, Van Groenweghe F, Delava P, Kalmar I, Vanrompay D: Tetracycline-resistant Chlamydia suis in cases of reproductive failure on Belgian, Cypriote and Israeli pig production farms. J Med Microbiol 2013, 62:331-334.

14. Borel N, Regenscheit N, Di Francesco A, Donati M, Markov J, Masserey Y, Pospischil A: Selection for tetracycline-resistant Chlamydia suis in treated pigs. Vet Microbiol 2012, 156(1-2):143-146

15. De Puysseleyr K, De Puysseleyr L, Geldhof J, Cox E, Vanrompay D: Development and validation of a real-time PCR for chlamydia suis diagnosis in swine and humans. PLoS One 2014, 9(5):e96704.

16. Suchland RJ, Sandoz KM, Jeffrey BM, Stamm WE, Rockey DD: Horizontal transfer of tetracycline resistance among Chlamydia spp. In vitro. Antimicrob Agents Ch 2009, 53(11):4604-4611.

17. Everett KDE, Bush RM, Andersen AA: Emended description of the order Chlamydiales, proposal of Parachlamydiaceae fam. nov. and Simkaniaceae fam. nov., each containing one monotypic genus, revised taxonomy of the family Chlamydiaceae, including a new genus and five new species, and standards for the identification of organisms. Int I Syst Bacteriol 1999, 49:415-440

18. Dickx V, Geens T, Deschuyffeleer T, Tyberghien L, Harkinezhad T, Beeckman DSA, Braeckman L, Vanrompay D: Chlamydophila psittaci zoonotic risk assessment in a chicken and turkey slaughterhouse. J Clin Microbiol 2010, 48(9):3244-3250. 
19. Wilson PA, Phipps J, Samuel D, Saunders NA: Development of a simplified polymerase chain reaction-enzyme immunoassay for the detection of Chlamydia pneumoniae. J Appl Bacteriol 1996, 80(4):431-438.

20. Pantchev A, Sting R, Bauerfeind R, Tyczka J, Sachse K: Detection of all Chlamydophila and Chlamydia spp. of veterinary interest using species-specific real-time PCR assays. Comp Immunol Microbiol 2010, 33(6):473-484

21. Schuurs TA, Verweij SP, Weel JFL, Ouburg S, Morre SA: Detection of Chlamydia trachomatis and Neisseria gonorrhoeae in an STI population: performances of the Presto CT-NG assay, the Lightmix Kit 480 HT CT/NG and the COBAS Amplicor with urine specimens and urethral/ cervicovaginal samples. BMJ Open 2013, 3(12).

22. Vanrompay D, Ducatelle R, Haesebrouck F: Diagnosis of avian chlamydiosis - specificity of the modified gimenez staining on smears and comparison of the sensitivity of isolation in eggs and 3 different cell-cultures. J Vet Med B 1992, 39(2):105-112.

23. Lagae S, Kalmar I, Laroucau K, Vorimore F, Vanrompay D: Emerging Chlamydia psittaci infections in chickens and examination of transmission to humans. J Med Microbiol 2014, 63:399-407.

24. Dugan J, Rockey DD, Jones L, Andersen AA: Tetracycline resistance in Chlamydia suis mediated by genomic islands inserted into the chlamydial inv-like gene. Antimicrob Agents Ch 2004, 48(10):3989-3995.

25. Sachse $K$, Hotzel H, Slickers P, Ellinger T, Ehricht R: DNA microarray-based detection and identification of Chlamydia and Chlamydophila spp. Mol Cell Probe 2005, 19(1):41-50.

26. Dean D, Rothschild J, Ruettger A, Kandel RP, Sachse K: Zoonotic Chlamydiaceae species associated with Trachorna, Nepal. Emerg Infect Dis 2013, 19(12):1948-1955.

27. Camenisch U, Lu ZH, Vaughan L, Corboz L, Zimmermann DR, Wittenbrink MM, Pospischil A, Sydler T: Diagnostic investigation into the role of Chlamydiae in cases of increased rates of return to oestrus in pigs. Vet Rec 2004, 155(19):593-596.

28. Lenart J, Andersen AA, Rockey DD: Growth and development of tetracycline-resistant Chlamydia suis. Antimicrob Agents Ch 2001, 45(8):2198-2203.

doi:10.1186/s12879-014-0560-x

Cite this article as: De Puysseleyr et al.: Evaluation of the presence and zoonotic transmission of Chlamydia suis in a pig slaughterhouse. BMC Infectious Diseases 2014 14:560.

\section{Submit your next manuscript to BioMed Central and take full advantage of:}

- Convenient online submission

- Thorough peer review

- No space constraints or color figure charges

- Immediate publication on acceptance

- Inclusion in PubMed, CAS, Scopus and Google Scholar

- Research which is freely available for redistribution 